\title{
Perennial grass abundance along a grazing gradient in Mendoza, Argentina
}

\author{
JORGE M. GONNET, JUAN C. GUEVARA, AND OSCAR R. ESTEVEZ
}

Gonnet is postdoctoral fellow; Guevara is Research Scientist; Estevez is Research Assistant, Plant and Livestock Production Unit, Instituto Argentino de Investigaciones de las Zonas Aridas (IADIZA), CC 507 (5500) Mendoza, Argentina.

Abstract

The study analyzed the basal area and density of perennial grasses along a cattle grazing intensity gradient away from a water development. Several mechanisms explaining combinations of changes in basal area and density with increasing grazing intensity were proposed. There was a curve-linear gradient of decreasing utilization of grasses at greater distances from water, and that gradient declined at greater distances from water. Basal diameter and density of 8 grasses were recorded at 11 distances from water ranged from 0.1 to $4.6 \mathrm{~km}$ within $16,1-\mathrm{m}^{2}$ plots for each distance. Circular basal area for each species was derived from its mean basal diameter. Plant density was estimated counting each tussock for bunchgrasses and each tiller as an individual for the 1 rhizomatous grass. The abundance of basal area and density to the gradient of distance from water was analyzed for grasses grouped according to their selectivity by cattle (undesirable, preferred, desirable, and secondary preference) and for the major preferred grass, Chloris castilloniana Lillo \& Parodi and the 2 undesirable grasses, Aristida invers $a$ Haeck. and $A$. mendocina Phil. Distance from water was regressed separately on basal area and on density for each selectivity group and each individual species. Basal area of total, undesirable, and desirable grasses increased up to intermediate distances from water and decreased at sites farther from water. Basal area of both the preferred grasses combined and the major preferred species increased linearly with distance from water. Basal area of $A$. inversa showed the same trend as the undesirable grasses while basal area of $A$. mendocina showed no definite pattern with increasing grazing intensity. Basal area of secondary preference species showed no definite pattern with distance from water. Density of total and desirable grasses increased up to intermediate distances from water and decreased at sites farther from water. Density of preferred species combined and the major preferred grass increased linearly with distance from water. Density of the 2 undesirable grasses and the secondary preference grass showed no definite trend with increasing grazing intensity. The combined patterns of basal area and density across the grazing intensity gradient suggest that the expression of recruitment, mortality, and plant growth (or shrinkage) in relation to grazing intensity varies among species and at different levels of grazing intensity. However, controlled experiments are needed to decipher the relative contributions of grazing intensity, neighboring species composition, or vegetation patterns existing before the establishment of the livestock water in the patterns of abundance.

Key Words: distance from water, basal area, plant density

Authors thank Mitchel P. McClaran and 2 anonymous referees for providing valuable comments on previous versions of the manuscript. Thanks are extended to Marta N. Paez for field assistance.

Manuscript accepted 3 Sept. 02.

\section{Resumen}

El estudio analizó el área basal y la densidad de las gramíneas perennes a lo largo de un gradiente de intensidad de pastoreo por bovinos a partir del punto de provisión de agua. Se propusieron varios mecanismos para explicar las combinaciones de cambios en área basal y densidad con el incremento de la intensidad de pastoreo. Se verificó un gradiente de utilización decreciente de los pastos a mayores distancias desde la aguada que respondió a una función curvilínea; dicho gradiente declinó a mayores distancias desde la aguada. Se midieron el diámetro basal y la densidad de 8 gramíneas en 11 distancias desde la aguada $(0,1$ a $4,6 \mathrm{~km})$, en 16 parcelas de $1 \mathrm{~m}^{2}$ en cada distancia. El área basal circular para cada especie se derivó de su diámetro basal medio. La densidad de plantas se estimó contando cada mata de las gramíneas amacolladas y cada vástago de la gramínea rizomatosa como un individuo. La abundancia de área basal y densidad en función del gradiente de distancia desde la aguada se analizó para las gramíneas agrupadas de acuerdo a su selectividad por los bovinos (indeseables, preferidas, deseables y de preferencia secundaria), para la gramínea preferida más importante, Chloris castilloniana Lillo \& Parodi, y para las 2 gramíneas indeseables, Aristida inversa Haeck y A. mendocina. Se estimaron regresiones entre área basal y distancia desde la aguada y entre densidad y distancia desde la aguada para cada grupo de gramíneas y para cada una de las tres especies individuales. El área basal del total de gramíneas y de las especies indeseables y deseables se incrementó hasta distancias intermedias desde la aguada y decreció a distancias más alejadas. El área basal de las especies preferidas combinadas y de la especie preferida más importante se incrementó linealmente con la distancia desde la aguada. El área basal de Aristida inversa mostró la misma tendencia que el conjunto de las especies indeseables, mientras que el área basal de $A$. mendocina no mostró un patrón definido con la distancia desde la aguada. El área basal de la gramínea de preferencia secundaria no mostró una tendencia definida con la distancia desde la aguada. La densidad del total de especies y de las gramíneas deseables se incrementó hasta distancias intermedias desde la aguada y decreció a distancias más alejadas. La densidad de las especies preferidas combinadas y la de la especie preferida principal aumentó linealmente con la distancia desde la aguada. La densidad de las 2 especies indeseables y la de la especie de preferencia secundaria no mostraron una tendencia definida con el gradiente de intensidad de pastoreo. Los patrones combinados de área basal y densidad a través del gradiente de intensidad de pastoreo sugieren que la manifestación de reclutamiento de individuos, mortalidad y crecimiento de plantas (o encogimiento) en relación con la intensidad de pastoreo varía entre especies y a diferentes niveles de intensidad de pastoreo. Sin embargo, se requieren experimentos controlados para descifrar las contribuciones relativas a los patrones de abundancia de factores tales como la intensidad de pastoreo, la composición de las especies vecinas o los patrones de vegetación existentes antes del establecimiento de la aguada. 
In arid regions, artificial watering points are the most common water sources for livestock. Location of water has an important effect on stock movements and livestock in turn will affect the abundance and diversity of forage species within paddocks (Stuth 1991). Regular movement of animals from forage to water produces a gradient of decreasing intensity of grazing and trampling from the vicinity of watering points to sites far from water (Lange 1969, Walker and Heitschmidt 1986, Andrew 1988, James et al. 1999). On the other hand, the extent of the impact of watering points on grass biomass appears to be related to rainfall in previous year (Guevara et al. 2001).

Major vegetation changes along the gradient occurs particularly in perennial grasses which are virtually eliminated or replaced by unpalatable and/or short-lived grasses, shrubs, and poisonous plants in zones close to water (Adámoli et al. 1990, Beeskow et al. 1995, Fusco et al. 1995, Saba et al. 1995). In a previous study (Guevara et al. 2001), we showed that response of grass abundance, in terms of above-ground biomass, to a grazing gradient further from water was predicted by the degree at which grasses were selected by cattle. However, in Mongolia, the abundance of biomass and cover along a gradient of grazing intensity varied along an aridity gradient, where declines in biomass and cover occurred with increased grazing intensity in mesic areas, but in arid areas the abundances were related to inter-annual precipitation rather than grazing intensity (Fernandez-Gimenez and Allen-Diaz 1999). Angell and McClaran (2001) noted a general absence of grass density response to a grazing intensity gradient up to $500 \mathrm{~m}$ from water over 28 years. Whereas, Fuhlendorf et al. (2001) noted some inverse relationships between grass density and individual plant basal areas as grazing intensity increased. This latter study illustrates the benefits of combining measures of density (number of plants) and cover (plant size) to interpret the mechanisms of vegetation response to different levels of grazing intensity. When taken alone, each measure can only provide 3 general responses: increase, decrease or neutral. However, in combination, there are 9 possible patterns of plant response, and the interpretation of possible mechanisms driving these responses is considerably richer (Table 1). For example, when only a positive change in cover and density occur simultaneously, then the interpretation will focus on mechanisms that stimulate both increases in plant size and plant number. In contrast, only a less focused interpretation would occur if only cover was measured.

Our objectives are to compare the abundance of different species exposed to increasing levels of grazing intensity, and to compare these patterns of abundance when measured as plant cover and density.

\section{Materials and Methods}

\section{Study area}

This study was conducted at El Divisadero Cattle and Range Experiment Station $\left(33^{\circ} 45^{\prime} \mathrm{S}, 67^{\circ} 41^{\prime} \mathrm{W}\right.$, elev. 520 $\mathrm{m})$, in the north central Mendoza plain, mid-west Argentina. Daily mean minimum and maximum temperatures annually range from -0.9 to $16.0^{\circ} \mathrm{C}$, and 14.9 to $32.4^{\circ} \mathrm{C}$, respectively. Mean annual rainfall for 1987-98 was $303.4 \mathrm{~mm}$ (SD = 96.6) with nearly $85 \%$ occurring during the growing season (October-March). Soils are Torripsamments with greater silt content in interdunal depressions.

The vegetation is an open xerophytic savanna and shrubland of Prosopis flexuosa DC. (algarrobo dulce). Warm-season grasses dominate the herbaceous vegetation. These species include: Aristida inversa Haeck. (flechilla), Aristida mendocina Phil. (flechilla crespa), Chloris castilloniana Lillo \& Parodi (falso plumerito), Digitaria californica (Benth.) Henr. (pasto algodón), Panicum urvilleanum Kunth (tupe), Pappophorum philippianum Roseng. (pasto blanco), Setaria leucopila (Scrib. \& Merr.) Schum. (cola de zorro), and Sporobolus cryptandrus (Torr.) A. Gray (gramilla cuarentona). Panicum urvilleanum is a rhizomatous species and the others are tussock grasses.

The grazing history of the range is not well known until 1980 when the Experiment Station was established. The grazing by livestock appears to begin after
1910 (Guevara et al. 2001). During the 1930 's the range was heavily grazed (11 ha $\mathrm{AU}^{-1}$ ) mainly by cattle. Because the range was not fenced, the estimation of this stocking rate assumed that livestock used all the range. Data obtained in 1976 (Guevara et al. 1981) showed that stocking rate had been reduced from 11 to 15 ha $\mathrm{AU}^{-1}$. In 1980 the range was fenced and livestock was removed. A 4-pasture (1,150 ha each), 1-herd grazing rotation system was installed in 5,000 ha of the range in 1990. The grazing system design involving paddocks radiating from a central watering point. A cow-calf operation with Angus and Criollo Argentino breeds was introduced at this time. The stocking rate ranged from about 40 ha $\mathrm{AU}^{-1}$ in $1990-91$ to $25 \mathrm{ha} \mathrm{AU}^{-1}$ from 1995 onwards. The latter corresponds to a conservative rate based on $30 \%$ use of forage by weight and the dependable annual rains, i.e. those having $80 \%$ probability of occurrence (Guevara et al. 1997). Removal of livestock during 10 years (1980-90) may have ameliorated the previous impact of grazing intensity on perennial grasses. In fact, above-ground biomass of grasses grouped according to their selectivity by cattle showed no definite pattern with distance from water in 1991-92 (Guevara et al. 2001).

\section{Sampling, calculations and statisti- cal analyses}

A homogeneous paddock, in terms of soil, vegetation, and topography, was selected to sample vegetation along a transect originating from the watering point. Individual basal diameter to the nearest 1 $\mathrm{mm}$ and density of each perennial grass were recorded at increasing distances $(0.1$, $0.4,0.7,1.0,1.3,1.65,1.875,2.5,3.25$, 3.95 , and $4.6 \mathrm{~km}$ ) from water within 16,1 $\mathrm{m}^{2}$ plots for each distance. Plots were arrayed at fixed distances $(30 \mathrm{~m})$ along a transect placed perpendicular to the main gradient.

Table 1. Mechanisms that can create the spatial differences in the abundance of grass basal area and density along the grazing intensity gradient.

\begin{tabular}{|c|c|c|c|c|}
\hline & & \multicolumn{3}{|c|}{ Differences in density with increasing grazing intensity } \\
\hline & & Positive (A) & Neutral (B) & Negative (C) \\
\hline \multirow{3}{*}{ 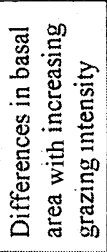 } & Positive (I) & more plants & bigger plants & $\begin{array}{c}\text { bigger and fewer } \\
\text { plants }\end{array}$ \\
\hline & Neutral (II) & $\begin{array}{l}\text { smaller and more } \\
\text { plants }\end{array}$ & $\begin{array}{l}\text { same number and } \\
\text { size of plants }\end{array}$ & $\begin{array}{c}\text { larger and fewer } \\
\text { plants }\end{array}$ \\
\hline & $\begin{array}{l}\text { Negative } \\
\text { (III) }\end{array}$ & $\begin{array}{l}\text { smaller and more } \\
\text { plants }\end{array}$ & smaller plants & $\begin{array}{l}\text { smaller and fewer } \\
\text { plants }\end{array}$ \\
\hline
\end{tabular}


The gradient of decreasing grazing intensity with distance from water was verified by an analysis of utilization based on the percent ungrazed method (Roach 1950). All plant species were measured at each distance. Observed utilization in 2001-2002 (a wet period) ranged from $50.4 \%$ at $0.1 \mathrm{~km}$ from water to $18.6 \%$ at $4.6 \mathrm{~km}$ from water. Utilization decreases with increasing distance from water according to the curve-linear function (Fig. 1).

Basal diameter was taken as the average of the longest diameter and the greatest perpendicular to the first. The circular basal area for each individual grass species $\left(\mathrm{mm}^{2}\right.$ plant $\left.^{-1}\right)$ was derived from this average basal diameter. For plant density (plants $\mathrm{m}^{-2}$ ) estimation, each tussock and each tiller was counted as an individual for the bunchgrasses and the rhizomatous grass, respectively. Therefore, density equals number of tillers for the 1 desirable species, Panicum urvilleanum, because it is rhizomatous.

To analyze the pattern of abundance of grass basal area and density in relation to the gradient of grazing intensity, the species were grouped according to their selectivity by cattle after Guevara et al. (1996) as: preferred (Chloris castilloniana, Digitaria californica, Pappophorum philippianum and Sporobolus cryptandrus), desirable (Panicum urvilleanum), secondary preference (Setaria leucopila), and undesirable (Aristida inversa and A. mendocina). Mean basal area and mean density were calculated for each grass selectivity group at each distance. The relationship of basal area and density to the gradient from water was also analyzed for the major preferred grass, Chloris castilloniana whose contribution to preferred grass basal area and density was 74 and $64 \%$, respectively, and for the 2 undesirable grasses (Aristida inversa and $A$. mendocina).

Distance from water was regressed separately on basal area and on density for each selectivity group and each individual grass species. Least squares method was used for obtaining estimates of parameters in linear and non-linear regression models.

\section{Results and Discussion}

\section{Relationship between basal area and distance from water}

Contribution of species to total basal area was: undesirable species, $72 \%$; preferred species, $16 \%$; secondary preference species, 9\%; and desirable species, $3 \%$.
Basal area was significantly related to distance from water for total (Fig. 2A), undesirable (Fig. 2B), preferred (Fig. 2C), and desirable (Fig. 2D) grasses. On the contrary, basal area of secondary preference species showed no definite pattern with distance from water (Fig. 2E). Basal area of total, undesirable, and desirable grasses increased up to about $1.9,1.9$, and $2.5 \mathrm{~km}$ from water, respectively, and decreased at sites farther from water (Fig. 2). These distances nearly coincide with a noticeable decrease in observed grass utilization levels between 1.3 and $1.9 \mathrm{~km}$ from water (Fig. 1). Conversely, basal area of preferred grasses increased linearly with increasing distance from water. As it was mentioned above, undesirable species were the most important contributors to total basal area of grasses and, thus, it appears that the abundance of total grasses is driven largely by the abundance of undesirable grasses.

The analysis of basal area abundance for individual grass species indicated that basal area was significantly related to distance from water for Chloris castilloniana (Fig. 3A) and Aristida inversa (Fig. 3B). Conversely, basal area of Aristida mendocina showed no definite pattern with distance from water (Fig. 3C).

Because basal area proved to be a good predictor of biomass for the grasses included in the present study (Guevara et al. 2002), in our previous study (Guevara et al. 2001) biomass of undesirable and preferred species showed the same pattern as basal area with distance from water. Furthermore, biomass distribution of secondary preference species showed a definite pattern with distance from water (Guevara et al. 2001).

\section{Relationship between grass density and distance from water}

Density was significantly related to distance from water for total (Fig. 4A), preferred (Fig. 4C) and desirable grasses (Fig. 4D). Measured density of total and desirable grasses increased up to about 1.9 and $2.5 \mathrm{~km}$ from water, respectively, and decreased at sites farther from water. As occurred with basal area, these distances nearly coincide with a noticeable decrease in observed grass utilization levels between 1.3 and $1.9 \mathrm{~km}$ from water (Fig. 1). The density of total grasses appears to be driven largely by the abundance of the desirable grass whose density contributed $72 \%$ to total grass density. Contribution of the other grasses to total density was: undesirable, $14 \%$; preferred, $9 \%$; and secondary preference, $5 \%$. Undesirable (Fig. 4B) and secondary preference (Fig. 4E) grasses showed no definite pattern with distance from water. Density was significantly related to distance from water for Chloris castilloniana (Fig. 5A) but density of Aristida inversa (Fig. 5B) and A. mendocina (Fig. 5C) showed no definite trend with distance from water.

The positive relationship between distance to water and density of preferred species and the absence of any relationship for secondary preference species are similar relationships reported for the distribution of biomass for these species (Guevara et al. 2001).

\section{Integration of trends in basal area and density along the grazing inten- sity gradient}

The response of grass basal area and density to changes in grazing intensity can

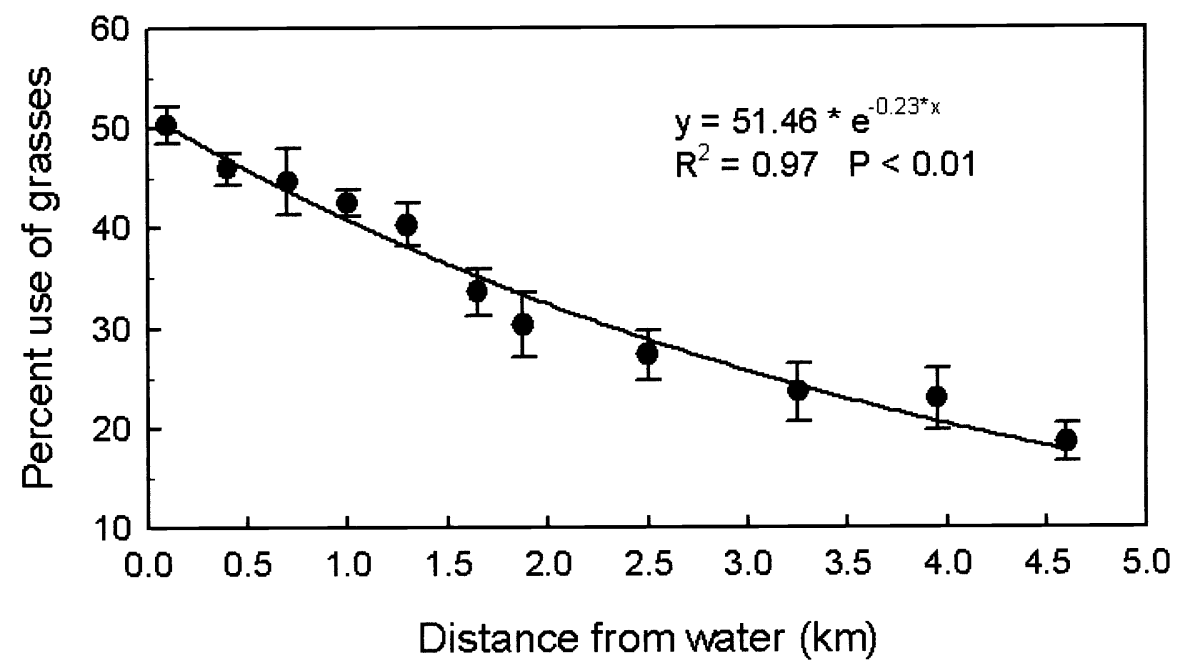

Fig. 1. Utilization of grasses as determined by the distance from water on a Mendoza plain rangeland. Vertical bars are one SE of the mean. 


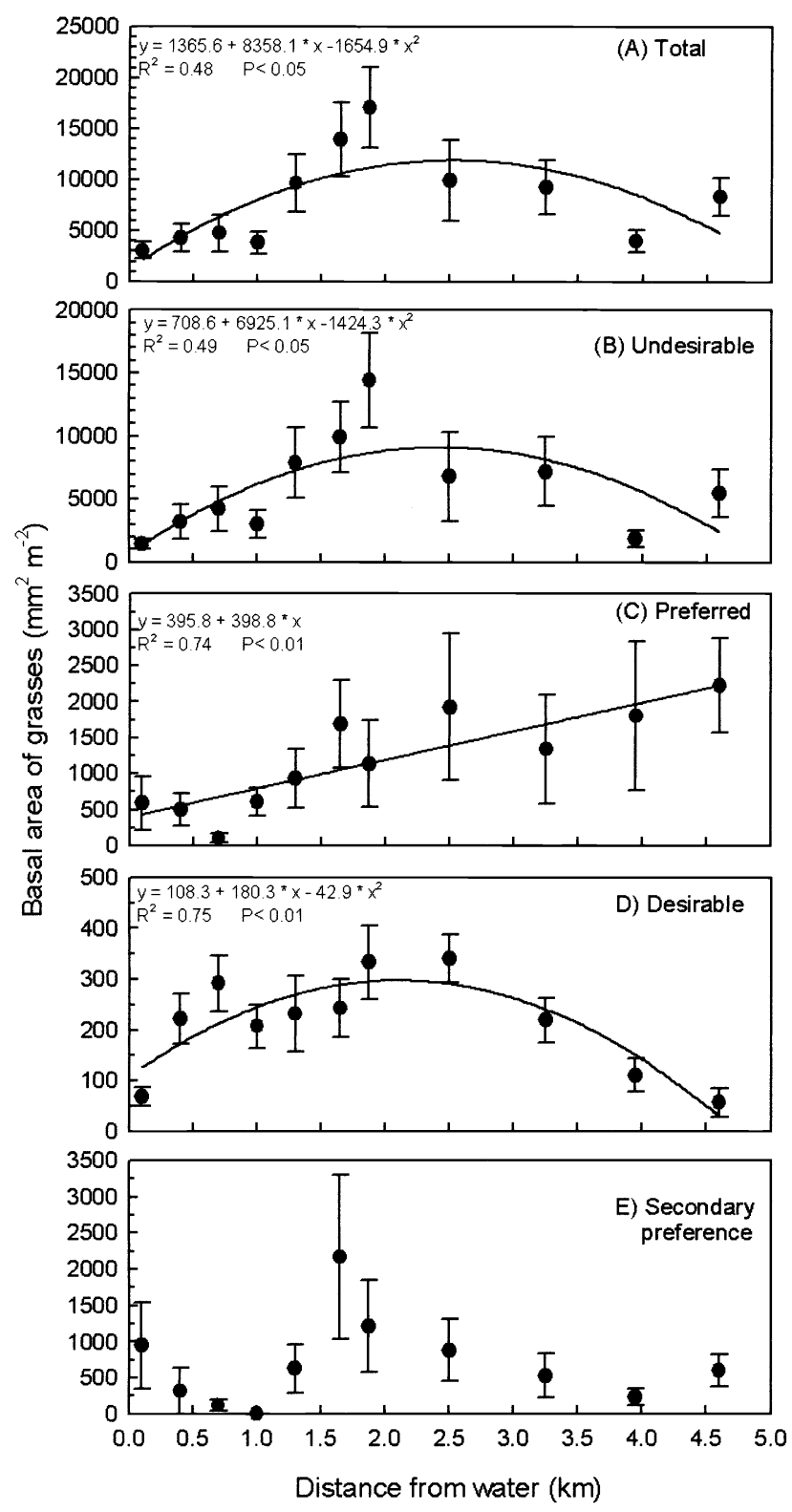

Fig. 2. Relationship between mean basal area for total grasses and grass species grouped according to their selectivity by cattle and distance from water on a Mendoza plain rangeland. Vertical bars are one SE of the mean.

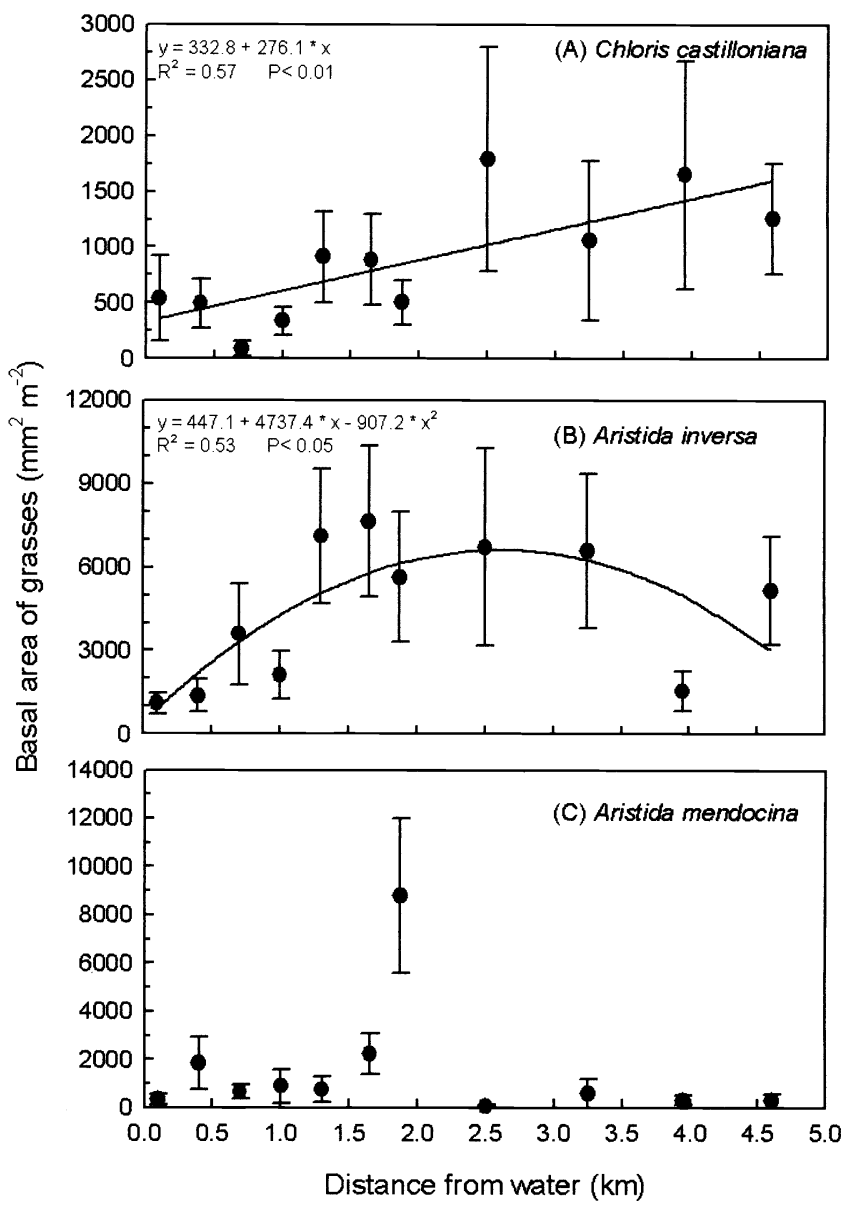

Fig. 3. Relationship between mean basal area for individual grass species and distance from water on a Mendoza plain rangeland. Vertical bars are one SE of the mean. be dependent on the level of grazing: whether from lowest to intermediate intensity or from intermediate to highest intensity. For total and desirable grasses, both basal area and density increased from sites farthest from water to those located at intermediate distances from water. The recruitment of tillers-for the desirable grass and individuals for tussock grasses is suggested as the mechanism creating this pattern (Table 1 , cell I A). On the contrary, tiller or plant mortality could be the mechanism creating the pattern observed in basal area and density at sites of the gradient located between those intermedi- ate distances from water and zones close to water (Table 1, cell III C).

For the preferred grasses combined and particularly for Chloris castilloniana, plant mortality appears to be the mechanism causing the responses of basal area and density with increasing grazing intensity (Table 1, cell III C).

One interpretation for the increased basal area and neutral plant density for undesirable plants between the lowest grazing intensity locations and the intermediate intensity locations (between 4.6 and $1.9 \mathrm{~km}$ from water) is compensatory growth following defoliation (Table 1, cell
I B). Mechanisms such as the light quality, determined by canopy density, that reaches intercalary meristems (Deregibus et al. 1983), assimilate allocation, and hormone and water balance, among others (see McNaughton 1979, 1983 and references therein) may be responsible for this process. However, it is possible that these responses are a function of competitive relations with neighboring species that occur in differing amounts between these distances from water. On the other hand, mortality of tillers could be the mechanism creating the pattern observed at sites located between the intermediate distances 

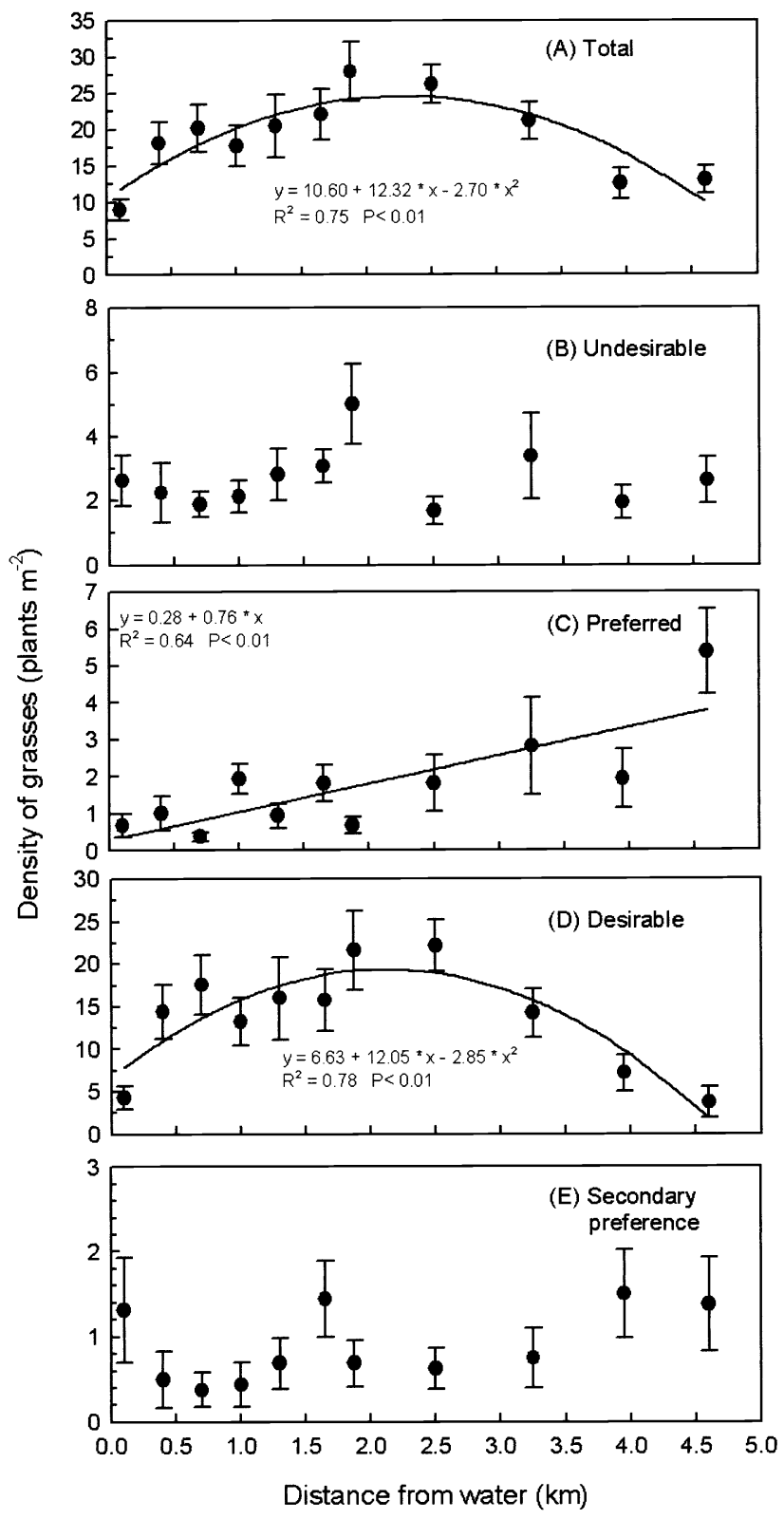

Fig. 4. Relationship between mean density for total grasses and grass species grouped according to their selectivity by cattle and distance from water on a Mendoza plain rangeland. Vertical bars are one SE of the mean.
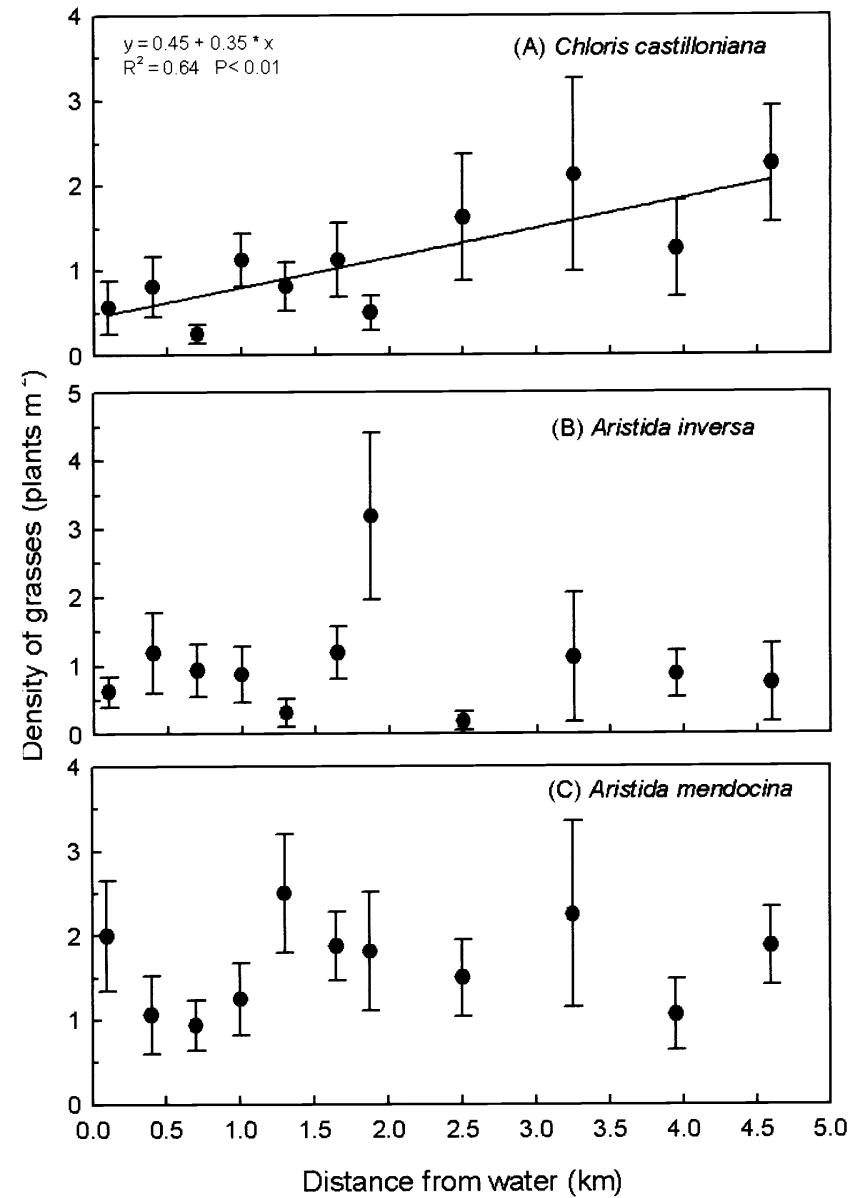

Fig. 5. Relationship between mean density for individual grass species and distance from water on a Mendoza plain rangeland. Vertical bars are one SE of the mean. from water and those located at the vicinity of watering points (Table 1, cell III B).

The abundance of basal area and density of Aristida inversa were similar to those for the class of undesirable grasses and consequently, the mechanisms mentioned for these species are applicable to this grass. This result can be explained by the significant contribution of $A$. inversa $(74 \%)$ to basal area of undesirable species. Conversely, Aristida mendocina and the secondary preference grass appear not to be affected by grazing intensity along the gradient from water.
Based on the measure of plant basal areas, the undesirable and desirable species could be considered increasers in the classification proposed by Dyksterhuis (1949). However, based on the measure of plant density, the undesirable species would not fit that scheme because it would be unresponsive to grazing intensity. In Australian shrublands (James et al. 1999) and in the Chihuahuan desert (Fusco et al. 1995), Aristida spp. are considered increasers based on the measure of plant density and biomass, respectively. Based on both area and density measures, pre- ferred species are clearly decreasers in the Dyksterhuis scheme. Similarly, in the Chihuahuan desert (Fusco et al. 1995) and Patagonia (Beeskow et al. 1995, Saba et al. 1995) patterns of declining abundance of the most preferred grasses by cattle around watering points were the most pronounced.

Mechanisms such as plant or tiller recruitment, plant or tiller mortality, and changes in plant size appear to be the mechanisms that create the observed patterns in basal area and density of perennial grasses along a grazing intensity gradient. 
The type and number of mechanisms creating the observed patterns depended on the grass selectivity group or individual grass species considered. Although the interpretation of mechanisms and possible processes driving these patterns of species abundance along the grazing intensity gradient are made richer by the combined measurement of density and basal area, in this case they do not provide evidence to judge the relative importance of utilization, the abundance of neighboring species, or the persistence of vegetation patterns established under different grazing practices. For example, was the increased size of Aristida inversa between 4.6 and $2.5 \mathrm{~km}$ from water a function of compensatory growth following moderate utilization, the decline in the abundance of neighboring preferred species, or an artifact of vegetation patterns existing before the establishment of the livestock water? Future experimentation that eliminates these confounding variables or the repeated measurement of these areas will help decipher the relative roles of utilization and neighbors in creating these patterns of species abundance along this grazing intensity gradient.

\section{Literature Cited}

Adámoli, J., E. Sennhauser, J.M. Acero, and A. Rescia. 1990. Stress and disturbance: vegetation dynamics in the dry Chaco region of Argentina. J. Biogeogr. 17:491-500.

Andrew, M.H. 1988. Grazing impact in relation to livestock watering points. Trends Ecol. Evol. 3:336-339.
Angell, D.L. and M.P. McClaran. 2001. Long-term influences of livestock management and a non-native grass on grass dynamics in the Desert Grassland. J. Arid Environ. 49:507-520.

Beeskow, A.M., N.O. Elissalde, and C.M. Rostagno. 1995. Ecosystem changes associated with grazing intensity on the Punta Ninfas rangelands of Patagonia, Argentina. J. Range Manage. 48:517-522.

Deregibus, V.A., R.A. Sánchez, and J.J. Casal. 1983. Effects of light quality on tiller production in Lolium spp. Plant Phys. 72:900-902.

Dyksterhuis, E.J. 1949. Condition and management of range land based on quantitative ecology. J. Range Manage. 2:104-115.

Fernandez-Gimenez, M.E., and B. AllenDiaz. 1999. Testing a non-equilibrium model of rangeland vegetation dynamics in Mongolia. J. Appl. Ecol. 36:871-885.

Fuhlendorf, S.D., D.D. Briske, and F.E. Smeins. 2001. Herbaceous vegetation change in variable rangeland environments: The relative contribution of grazing and climatic variability. Appl. Veg. Sci. 4:177-188.

Fusco, M., J. Holechek, A. Tembo, A. Daniel, and M. Cardenas. 1995. Grazing influences on watering point vegetation in the Chihuahuan desert. J. Range Manage. 48:32-38.

Guevara, J.C., J.M. Gonnet, and O.R. Estevez. 2001. Impact of cattle grazing on native perennial grasses in the arid rangelands of the Mendoza plain, Argentina, p. 69-86. In: I. Prakash (ed.), Ecology of Desert Environments (A Festschrift for Professor J.L. Cloudsley-Tompson on his $80^{\text {th }}$ Birthday). Scientific Publishers, Jodhpur, India.

Guevara, J.C., J.M. Gonnet, and O.R. Estevez. 2002. Biomass estimation for native perennial grasses in the plain of Mendoza, Argentina. J. Arid Environ. 50:613-619.
Guevara, J.C., C.R. Stasi, and O.R.Estevez. 1996. Seasonal specific selectivity by cattle on rangeland in the Monte Desert of Mendoza, Argentina. J. Arid Environ. 34:125-132.

Guevara, J.C., J.A. Paez, R.F. Tanquilevich, and O.R. Estevez. 1981. Economía de las explotaciones ganaderas, I. Tierras privadas del área centro este de la provincia de Mendoza (In Spanish). Cuaderno Técnico 4:1-39.

Guevara, J.C., J.B. Cavagnaro, O.R. Estevez, H.N. Le Houérou, and C.R. Stasi. 1997. Productivity, management and development problems in the arid rangelands of the central Mendoza plains (Argentina). J. Arid Environ. 35:575-600.

James, C.D., J. Landsberg, and S.R. Morton. 1999. Provision of watering points in the Australian arid zone: a review of effects on biota. J. Arid Environ. 41:87-121.

Lange, R.T. 1969. The piosphere: sheep track and dung patterns. J. Range Manage. 22:396-400.

McNaughton, S.J. 1979. Grazing as an optimization process: grass-ungulate relationships in the Serengeti. Amer. Nat. 113:691-703.

McNaughton, S.J. 1983. Compensatory plant growth as a response to herbivory. Oikos 40:329-336.

Roach, M.E. 1950. Estimating perennial grass utilization on semidesert ranges by percentage of ungrazed plants. J. Range Manage. 3:182-185.

Saba, S.L., D.A. Pérez, E. Cejuela, V. Quiroga, and A. Toyos. 1995. La piosfera ovina en el extremo austral del desierto del Monte (In Spanish). Naturalia patagónica 3:153-174.

Stuth, J.W. 1991. Foraging behavior, p. 65-84. In: R.K. Heitschmidt and J.W. Stuth (eds.), Grazing Management. An Ecological Perspective. Timber Press, Portland, Ore.

Walker, J.W. and R.K. Heitschmidt. 1986. Effect of various grazing systems on type and density of cattle trails. J. Range Manage. 39:428-431. 